\title{
Correction to: The Impact of Hospital Costing Methods on Cost-Effectiveness Analysis: A Case Study
}

\author{
José Leal ${ }^{1}$ - Stefania Manetti ${ }^{2}$. James Buchanan ${ }^{1}$ (D)
}

Published online: 5 March 2019

(c) The Author(s) 2019

\section{Correction to: PharmacoEconomics (2018) 36:1263-1272 https://doi.org/10.1007/s40273-018-0673-y}

The Open Access license, which previously read:

Open Access This article is distributed under the terms of the Creative Commons Attribution-NonCommercial 4.0 International License (http://creativecommons.org/licen ses/by-nc/4.0/), which permits any noncommercial use, distribution, and reproduction in any medium, provided you give appropriate credit to the original author(s) and the source, provide a link to the Creative Commons license, and indicate if changes were made.

Should read:

Open Access This article is distributed under the terms of the Creative Commons Attribution 4.0 International License (http://creativecommons.org/licenses/by/4.0/), which permits unrestricted use, distribution, and reproduction in any medium, provided you give appropriate credit to the original author(s) and the source, provide a link to the Creative Commons license, and indicate if changes were made.

The original article can be found online at https://doi.org/10.1007/ s40273-018-0673-y.

James Buchanan

james.buchanan@dph.ox.ac.uk

1 Health Economics Research Centre, Nuffield Department of Population Health, University of Oxford, Old Road Campus, Headington, Oxford OX3 7LF, UK

2 Institute of Management, Scuola Superiore Sant'Anna, Pisa, Italy
The original article has been corrected.

Open Access This article is distributed under the terms of the Creative Commons Attribution 4.0 International License (http://creativeco mmons.org/licenses/by/4.0/), which permits unrestricted use, distribution, and reproduction in any medium, provided you give appropriate credit to the original author(s) and the source, provide a link to the Creative Commons license, and indicate if changes were made. 